\title{
PELATIHAN PENGEMBANGAN ALAT PERAGA BANGUN DATAR BAGI GURU-GURU SDK St. ARNOLDUS PENFUI-KUPANG
}

\author{
Wara Sabon Dominikus ${ }^{1)}$, Juliana M.H. Nenohai ${ }^{2)}$, Damianus Dao Samo ${ }^{3)}$, \\ Patrisius A. Udil ${ }^{4)}$ \\ Universitas Nusa Cendana Kupang ${ }^{1234)}$ \\ Email:dominikus@staf.undana.ac.id ${ }^{1)}$
}

Diterbitkan: 28-02-2021

\begin{abstract}
Abstrak
Kegiatan pengabdian masyarakat dalam bentuk pelatihan pengembangan alat peraga bangun datar bagi guru-guru SDK St. Arnoldus Penfui Kupang ini bertujuan untuk meningkatkan kemampuan guru dalam: (1) membuat dan mengembangkan alat peraga matematika khususnya alat peraga bangun datar untuk pembelajaran matematika SD; (2) menggunakan alat peraga matematika khususnya alat peraga bangun datar dalam pembelajaran matematika SD; (3) mendesain dan melaksanakan pembelajaran matematika yang konkret dan relevan bagi siswa SD. Kegiatan pengabdian masyarakat ini dilakukan dalam bentuk workshop. Metode yang digunakan dalam pelaksanaan kegiatan ini antara lain seminar, presentasi materi, tanya jawab, diskusi, pelatihan, dan demonstrasi. Kegiatan ini dilaksanakan melalui dua tahapan tahapan yaitu tahap persiapan dan tahap pelaksanaan. Masing-masing tahap mencakup beberapa aktivitas. Kegiatan ini berjalan dan terlaksana dengan baik dan lancar sesuai dengan yang telah direncanakan. Hasil kegiatan ini menunjukkan keterlibatan dan partisipasi aktif guru-guru SDK St. Arnoldus Penfui Kupang. Selain itu, kegiatan ini juga dapat meningkatkan kemampuan guru-guru SDK St. Arnoldus Penfui Kupang untuk membuat, mengembangkan, dan menggunakan alat peraga bangun datar. Lebih lanjut, kegiatan ini juga menghasilkan beberapa jenis alat peraga bangun datar yang dibuat dan dikembangkan oleh guru-guru SDK St. Arnoldus Penfui Kupang.
\end{abstract}

Kata Kunci: Pembelajaran matematika, alat peraga, bangun datar.

\section{Pendahuluan}

Pembelajaran matematika pada jenjang Sekolah Dasar (SD) merupakan fondasi bagi siswa dalam mengikuti, memahami, dan mengaplikasikan konsep matematika baik dalam konteks kehidupan nyata maupun dalam pembelajaran matematika jenjang selanjutnya. Pembelajaran matematika SD tidak hanya terkait hitung menghitung tetapi terutama dimaksudkan untuk membangun kemampuan dasar terkait pemahaman konsep, ide-ide, aturan-aturan, logika matematika, menggunakan penalaran dan pembuktian untuk memecahkan masalah kehidupan. Hal ini menunjukkan bahwa pembelajaran matematika merupakan pembelajaran yang kompleks dan abstrak, sehingga menuntut guru untuk mendesain dan merencanakan pembelajaran yang sesuai dengan tingkat kemampuan siswa SD. 
Guru dituntut untuk mampu menjembatani konsep matematika yang abstrak dengan kemampuan berpikir siswa SD melalui desain pembelajaran yang menarik, konkret, dan menyenangkan. Dienes (Jannah, 2013) mengungkapkan bahwa setiap konsep atau prinsip matematika yang disajikan dalam bentuk konkret lebih mudah dicerna dan dipahami siswa. Hal ini pun sesuai dengan teori perkembangan kognitif Piaget yang menyatakan bahwa anak berusia 7-11 tahun berada pada level berpikir operational konkret yang lebih mudah mencerna dan memahami hal-hal konkret (Babakr, Mohamedamin, Kakamad, 2019). Dengan demikian, guru SD perlu mendesain dan melaksanakan pembelajaran yang memanfaatkan media-media konkret sehingga konsep-konsep matematika yang abstrak bisa dicerna dan dipahami oleh siswa SD.

Pembelajaran matematika masih menyisakan berbagai macam tantangan terutama bagi guru-guru pada jenjang SD. Salah satu tantangan yang paling banyak dijumpai guru SD adalah terkait dengan upaya membelajarkan konsep matematika dalam bentuk yang konkret. Bangun datar merupakan salah satu cakupan materi pada pembelajaran matematika SD yang sering menyulitkan guru dalam membelajarkannya. Kesulitan tersebut terutama terkait dengan isu bagaimana mendesain pembelajaran dan membelajarkan materi bangun datar secara konkret agar lebih mudah diterima, dicerna, dan dipahami siswa. Hal ini pun ditemukan dalam observasi yang dilakukan pada SDK St. Arnoldus Kupang. Guru-guru menyatakan pandangan yang kurang lebih sama terkait kesulitan untuk mendesain pembelajaran matematika yang menarik dan konkret. Siswa cenderung disajikan dan diberikan materi matematika yang abstrak secara langsung. Potret kemampuan siswa yang belum maksimal dalam menyelesaikan soal cerita bangun datar juga menjadi bukti bahwa pembelajaran matematika di SDK St. Arnoldus masih perlu ditingkatkan.

Pemanfaatan alat peraga merupakan salah satu alternatif solusi yang dapat menghadirkan pembelajaran matematika yang konkret dan relevan bagi siswa SD. Alat peraga matematika merupakan alat atau benda yang digunakan untuk menerangkan dan mewujudkan pengetahuan, fakta, konsep, prinsip, atau prosedur matematika tertentu sehingga tampak lebih nyata bagi siswa serta menjadi dasar proses berpikir abstrak (Estiningsih, 1994; Murdiyanto \& Mahatma, 2014). Alat peraga matematika tidak hanya menyajikan materi menjadi lebih nyata tetapi juga dapat menjadikan pembelajaran lebih menarik sehingga siswa lebih termotivasi untuk belajar. Dalam konteks sebagai media pembelajaran, Arsyad (Wahyuningtyas \& Shinta, 2017) menyebutkan beberapa fungsi alat peraga antara lain: (1) dapat memperjelas penyampaian pesan dan informasi sehingga dapat memperlancar pembelajaran dan meningkatkan prestasi, (2) dapat mengarahkan perhatian siswa terhadap materi, sehingga dapat menimbulkan motivasi untuk belajar, dan (3) dapat memberikan pengalaman kepada siswa, dan dapat mengaitkannya dalam kehidupan seharihari. Selanjutnya, Ruseffendi (Pujiati, 2009) menyebutkan beberapa persyaratan yang harus dimiliki alat peraga agar fungsi atau manfaat dari alat peraga tersebut sesuai dengan yang diharapkan dalam pembelajaran. Persyaratan yang dimaksud antara lain: 1) alat peraga harus sesuai dengan konsep matematika, 2) alat peraga dapat memperjelas konsep matematika, baik dalam bentuk real, gambar atau diagram dan bukan sebaliknya (mempersulit pemahaman konsep matematika), 3) alat peraga menjadi dasar bagi tumbuhnya konsep berpikir abstrak bagi siswa, karena alat peraga tersebut dapat dimanipulasi (dapat diraba, dipegang, dipindahkan, dipasangkan, 
dan sebagainya) agar siswa dapat belajar secara aktif baik secara individual maupun kelompok.

Penggunaan alat peraga dalam pembelajaran matematika SD diyakini dapat menjembatani konsep matematika yang abstrak dengan kemampuan berpikir siswa SD yang konkret. Oleh karena itu, peningkatan kapasitas, kualitas, dan kemampuan guru dalam mendesain, mengembangkan, dan menggunakan alat peraga matematika menjadi suatu hal yang perlu diperhatikan dan ditindaklanjuti. Hal inilah yang mendorong pelaksanaan kegiatan pengabdian masyarakat dalam bentuk pelatihan pengembangan alat peraga bangun datar bagi guru-guru SDK St. Arnoldus Penfui-Kupang.

\section{Metode Pelatihan}

Kegiatan pengabdian masyarakat ini dilakukan dalam bentuk workshop. Metode yang digunakan dalam pelaksanaan kegiatan ini antara lain seminar, presentasi materi, tanya jawab, diskusi, pelatihan, dan demonstrasi. Kegiatan ini dilaksanakan melalui beberapa tahapan yang diuraikan sebagai berikut.

1. Tahap Persiapan

Pada tahap ini dilakukan berbagai persiapan pelaksanaan kegiatan pengabdian masyarakat.

Tahap ini mencakup aktivitas orientasi dan observasi lapangan, koordinasi dan penetapan waktu pelaksanaan kegiatan, menyiapkan alat dan bahan untuk pengembangan alat peraga, menyiapkan materi pengembangan alat peraga, dan menyiapkan materi penggunaan alat peraga.

2. Tahap Pelaksanaan

Pada tahap ini dilaksanakan kegiatan pelatihan pengembangan alat peraga bangun datar bagi guru-guru SDK St. Arnoldus Penfui Kupang. Adapun pelaksanaan kegiatan ini meliputi beberapa aktivitas berikut.

a. Seminar

Kegiatan yang dilakukan antara lain pemaparan materi, diskusi, dan tanya jawab.

b. Pelatihan

Kegiatan yang dilakukan meliputi demonstrasi pembuatan alat peraga, pendampingan pengembangan alat peraga, dan pendampingan penggunaan alat peraga.

\section{Hasil dan Pembahasan}

Kegiatan pengabdian masyarakat ini dilaksanakan dalam bentuk workshop dan mencakup beberapa tahapan dan aktivitas. Kegiatan dimulai dari tahap persiapan yang meliputi beberapa aktivitas. Kemudian dilanjutkan dengan pelaksanaan kegiatan melalui seminar, presentasi materi dan pelatihan pengembangan alat peraga bangun datar bagi guru-guru SDK St. Arnoldus Penfui Kupang.

1. Tahap Persiapan

Persiapan kegiatan ini dimulai dari bulan Juni sampai Agustus 2020. Kegiatan persiapan ini mencakup beberapa aktivitas antara lain orientasi dan observasi lapangan, koordinasi dan 
penetapan waktu pelaksanaan kegiatan, menyiapkan alat dan bahan untuk pengembangan alat peraga, menyiapkan materi pengembangan alat peraga, dan menyiapkan materi penggunaan alat peraga. Orientasi dan obeservasi lapangan dilakukan pada tanggal 19 Agustus 2020. Orientasi dan observasi lapangan dimaksudkan untuk menggali informasi terutama kendala dan masalah yang dihadapi guru-guru SDK St. Arnoldus Penfui Kupang dalam membelajarkan matematika. Hasil observasi dan wawancara dengan guru-guru SDK St. Arnoldus menunjukkan bahwa pembelajaran matematika bagi siswa cenderung dilakukan secara langsung dan konvensional. Siswa disajikan materi dan konsep secara langsung melalui penjelasan dan ceramah guru. Dalam konteks pembelajaran bangun datar, penggunaan media pembelajaran seperti alat peraga sangat jarang dilakukan. Selanjutnya, pada tahap ini juga disepakati waktu pelaksanaan kegiatan bersama Kepala Sekolah dan guru-guru SDK St. Arnoldus Penfui Kupang yaitu pada tanggal 28-31 Agustus 2020. Setalah waktu pelaksanaan kegiatan disepakati bersama, persiapan lain yang dilakukan antara lain menyiapkan alat dan bahan untuk pengembangan alat peraga, materi pengembangan alat peraga, dan materi penggunaan alat peraga.

2. Tahap Pelaksanaan

Kegiatan pelatihan pengembangan alat peraga bangun datar bagi guru-guru SDK St. Arnoldus Penfui Kupang dilaksanakan selama 3 hari yaitu pada tanggal 28,28, dan 31 Agustus 2020. Kegiatan pelatihan dilaksanakan di salah ruangan kelas SDK St. Arnoldus Penfui Kupang dan diikuti oleh 27 peserta. Kegiatan dilaksanakan mulai pukul 08.00 WITA sampai pukul 16.00 WITA. Kegiatan yang dilakukan pada tahap ini meliputi beberapa aktivitas dan bentuk kegiatan yaitu seminar, presentasi materi, diskusi dan tanya jawab, pelatihan, serta demonstrasi pengembangan dan penggunaan alat peraga.

a. Seminar

Seminar dilakukan pada hari pertama kegiatan yaitu tanggal 28 Agustus 2020 Pukul 08.30-10.30 WITA. Aktivitas ini dimaksudkan untuk memberikan informasi dan pengetahuan kepada peserta kegiatan terkait alat peraga bangun datar dan pemanfaatannya dalam pembelajaran matematika SD.
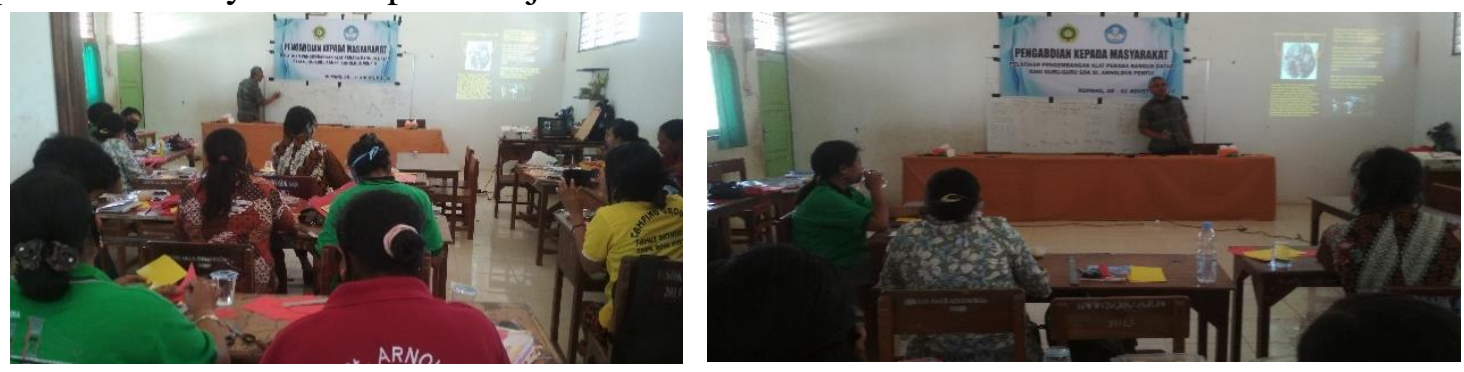

Gambar 1. Seminar Pemanfaatan Alat Peraga dalam Pembelajaran Matematika

b. Pelatihan Pembuatan dan Pengembangan Alat Peraga Bangun Datar

Kegiatan pelatihan pembuatan dan pengembangan alat peraga bangun datar bagi guru-guru SDK St. Arnoldus Penfui Kupang dilaksanakan dari tanggal 28 sampai 31 
Agustus 2020. Kegiatan ini dilakukan melalui pendampingan Tim PKM Program Studi Pendidikan Matematika Undana Kupang. Pada kegiatan pelatihan, guru-guru peserta kegiatan difasilitasi untuk membuat dan mengembangkan berbagai jenis alat peraga bangun datar. Pembuatan dan pengembangan alat peraga bangun datar dilakukan secara individual dan berkelompok melalui pendampingan Tim PKM Program Studi Pendidikan Matematika Undana.

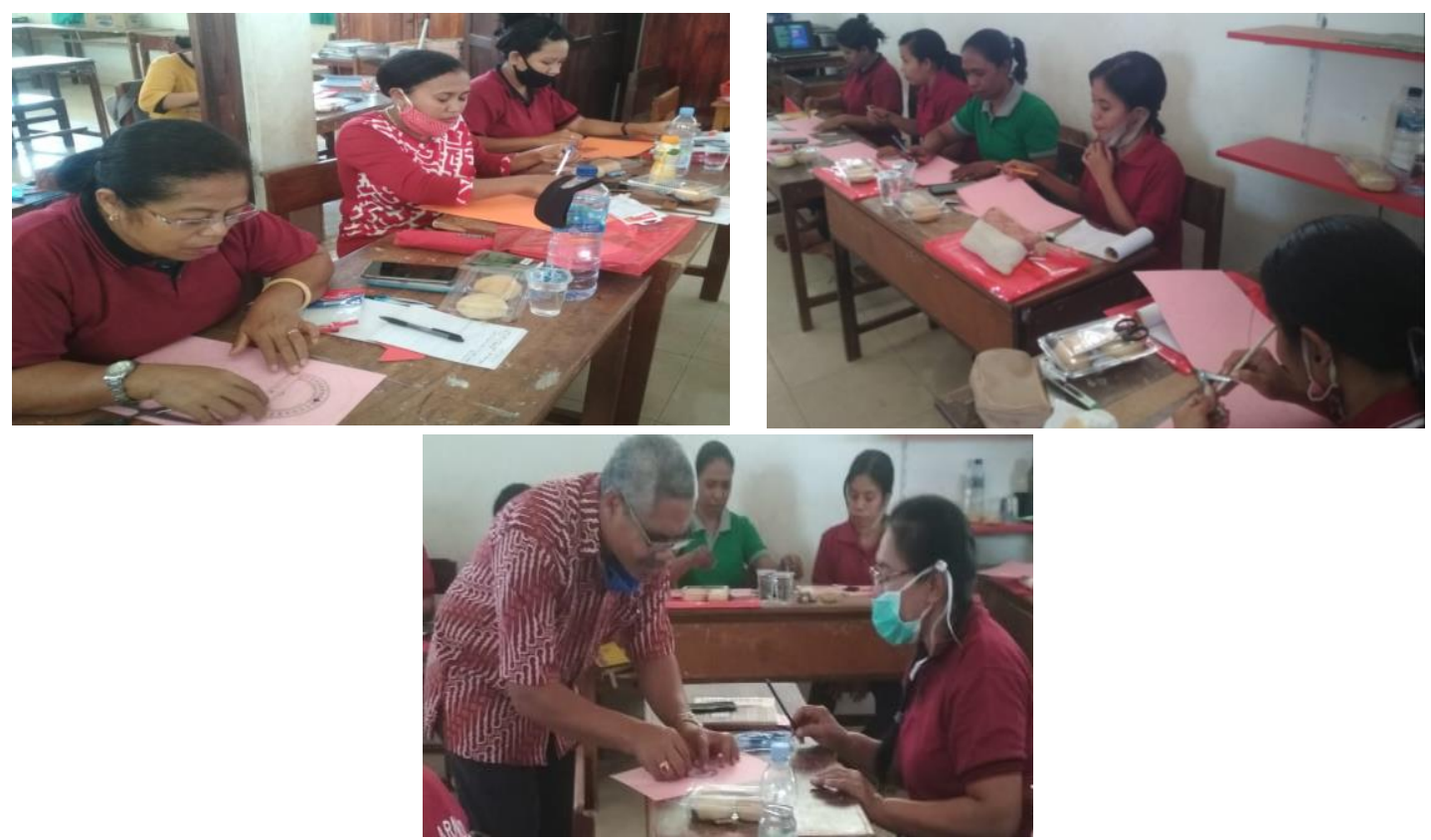

Gambar 2. Pelatihan Pembuatan dan Pengembangan Alat Peraga

Adapun alat peraga yang dihasilkan dari kegiatan pembuatan dan pengembangan ini antara lain alat peraga luas bangun datar persegi panjang, persegi, jajargenjang, trapesium, laying-layang, belah ketupat, segitiga, dan lingkaran. Pembuatan dan pengembangan alat peraga yang dimaksud tidak hanya dilakukan di kelas tetapi juga diberikan kesempatan bagi guru-guru untuk memodifikasi dan mengembangkannya lebih lanjut secara mandiri. Hasil kegiatan ini selama 3 hari menunjukkan bahwa $85 \%$ guru mampu mengikuti langkah-langkah pembuatan media alat peraga bangun datar dan membuat alat peraga bangun datar dari bahan yang disiapkan Tim PKM Undana. Guruguru SDK St. Arnoldus Penfui Kupang juga mampu mengembangkan lebih lanjut alat peraga bangun datar secara mandiri dan berkelompok. Hal ini menunjukkan bahwa melalui kegiatan pelatihan ini, guru-guru SDK St. Arnoldus Penfui Kupang dapat meningkatkan kemampuannya dalam mendesain, membuat, dan mengembangkan alat peraga bangun datar dengan memanfaatkan berbagai benda sederhana yang ada.

Hasil ini sejalan dengan temuan Muchlis, Rahimah, dan Maizora (2015) yang menyatakan bahwa kegiatan pelatihan pengembangan alat peraga matematika dapat meningkatkan kemampuan guru dalam menggunakan dan memanfaatkan benda yang ada 
di sekitar lingkungan untuk dijadikan alat peraga dalam pembelajaran. Selain itu, hasil kegiatan ini juga menunjukkan bahwa guru-guru SDK St. Arnoldus mampu untuk mengembangkan alat peraga bangun datar secara mandiri dan kreatif untuk digunakan dalam pembelajaran matematika SD. Deda dan Disnawati (2019) menemukan hal yang serupa terkait peningkatan kreatifitas guru SD dalam pembuatan media alat peraga luas bangun datar untuk mendukung pembelajaran di kelas setelah mengikuti workshop media alat peraga.

c. Pelatihan Penggunaan Alat Peraga Bangun Datar

Salah satu kendala dan masalah yang ditemukan saat observasi adalah kesulitan guru dalam melaksanakan pembelajaran yang konkret dan relevan dengan perkembangan kognitif siswa SD. Pemanfaatan alat peraga merupakan salah satu alternative solusi yang dapat mengatasi masalah tersbut. Oleh karena itu, penting untuk meningkatkan kemampuan dan kapasitas guru dalam memanfaatkan alat peraga yang telah dikembangkan sehingga pesan dan pengetahuan yang hendak dibelajarkan betul-betul sampai pada pemahaman siswa SD.

Pada kegiatan ini guru-guru SDK St. Arnoldus Penfui Kupang didampingi oleh Tim PKM Program Studi Pendidikan Matematika Undana untuk menggunakan alat peraga yang telah dikembangkan. Bentuk pendampingan yang dimaksud antara lain memfasilitasi guru-guru dalam sesi diskusi kelompok terkait penggunaan media alat peraga yang telah dibuat. Selain itu, pendampingan juga dilakukan dalam bentuk menyusun langkah-langkah kegiatan pembelajaran yang memanfaatkan alat peraga. Hasilnya guru-guru mampu merumuskan Lembar Kerja Peserta Didik yang berisi langkah-langkah aktivitas siswa dalam mempelajari konsep luas bangun datar dengan memanfaatkan alat peraga. Lebih lanjut diharapkan bahwa guru-guru mampu memfasilitasi siswa untuk mempelajari konsep luas bangun datar melalui alat peraga dan lembar kerja peserta didik yang telah dibuat. Hal ini senada dengan teori belajar Dienes (Jannah, 2013) yang mengungkapkan bahwa setiap konsep atau prinsip matematika yang disajikan dalam bentuk konkret lebih mudah dicerna dan dipahami siswa. Pembelajaran yang memanfaatkan media konkret seperti alat peraga diyakini dapat membantu siswa dalam memahami konsep matematika yang abstrak (Nasaruddin, 2015).

Dengan demikian, pembelajaran matematika yang memanfaatkan alat peraga perlu ditindaklanjuti dan dilaksanakan secara berkelanjutan sehingga pembelajaran materi dan konsep matematika yang abstrak bisa disajikan dalam bentuk yang konkret dan sesuai dengan perkembangan kognitif siswa SD. Lebih lanjut, hal ini dapat mempermudah siswa SD dalam mencerna dan memahami konsep matematika yang dipelajari.

\section{Simpulan}

Berdasarkan hasil dan pembahasan di atas disimpulkan bahwa kegiatan pelatihan pengembangan alat peraga bangun datar bagi guru-guru SDK St. Arnoldus Penfui Kupang dapat meningkatkan kemampuan guru-guru untuk membuat alat peraga bangun datar. Selain itu, 
kegiatan ini juga dapat meningkatkan kemampuan guru-guru SDK St. Arnoldus Penfui Kupang dalam mengembangkan alat peraga secara mandiri dan menggunakannya dalam pembelajaran matematika. Lebih lanjut, kegiatan ini juga menghasilkan beberapa jenis alat peraga bangun datar yang dibuat dan dikembangkan oleh guru-guru SDK St. Arnoldus Penfui Kupang.

\section{Ucapan Terimakasih}

1. Ucapan terimakasih kepada Dekan Fakultas Keguruan Ilmu Pendidikan Universitas Nusa Cendana yang telah mengijinkan Tim PKM melaksanakan Program Kemitraan Masyarakat.

2. Ucapan terimakasih kepada Kepala SDK St. Arnoldus Penfui Kupang yang telah berkenan memberikan berbagai data terkait kegiatan pengabdian yang dilaksanakan oleh Tim PKM Program Studi Pendidikan Matematika FKIP Universitas Nusa Cendana.

3. Ucapan terimakasih kepada guru-guru SDK St. Arnoldus Penfui Kupang yang telah berpartisipasi aktif dalam kegiatan pelatihan dari awal sampai akhir kegiatan.

\section{Daftar Pustaka}

Babakr, Z. H., Mohamedamin, P., \& Kakamad, K. (2019). Piaget's Cognitive Developmental Theory: Critical Review. Education Quarterly Reviews, 2(3), 517-524.

Deda, Y. N. \& Disnawati, H. 2019. Workshop Media Alat Peraga Matematika "Luas Bangun Datar" untuk Meningkatkan Kreatifitas Guru dan Siswa Sekolah Dasar. Ethos: Jurnal Pengabdian Masyarakat, 8(1), 67-72.

Estiningsih, E. (1994). Landasan Teknik Pengajaran Hitung SD. Yogyakarta: PPPG Matematika. Jannah, U. R. (2013). Teori Dienes dalam Pembelajaran Matematika. Interaksi, 8(2), 126-131.

Muchlis, E.E., Rahimah, D., \& Maizora, S. (2015). Pelatihan Pembuatan Alat Peraga Matematika Berbasis Lingkungan untuk Meningkatkan Kompetensi Guru SD dalam Pelaksanaan Kurikulum 2013 di Kota Bengkulu. Dharma Raflesia: Jurnal Ilmiah Pengembangan dan Penerapan IPTEKS, 13(2), 167-172.

Murdiyanto, T. \& Mahatma, Y. (2014). Pengembangan Alat Peraga Matematika untuk Meningkatkan Minat dan Motivasi Belajar Matematika Siswa Sekolah Dasar. Sarwahita: Jurnal Pengabdian Kepada Masyarakat, 11(1), 38-43.

Nasaruddin. (2015). Media dan Alat Peraga dalam Pembelajaran Matematika. Al-Khwarizmi: Jurnal Pendidikan Matematika dan Ilmu Pengetahuan Alam, 3(2), 21-30.

Pujiati. (2009). Pemanfaatan Alat Peraga Sebagai Media Pembelajaran Matematika SD. Makalah tidak dipublikasikan. Yogyakarta: PPPPTK Matematika.

Wahyuningtyas, D. T. \& Shinta, R. N. (2017). Pelatihan Media Pembelajaran Matematika Berdasarkan Kurikulum 2013 Bagi Guru Sekolah Dasar di Gugus 9 Kecamatan Sukun Malang. Jurnal Dedikasi, 14, 08-11. 